УДК: 351.77:616-036.21

DOI: https://doi.org/10.18485/fb_covid19.2020.ch3

\title{
ЗДРАВСТВЕНИ И БЕЗБЕДНОСНИ АСПЕКТИ КОВИДА 19
}

\author{
проф. др Елизабета Ристановић ${ }^{1}$
}

Апстракт: Пандемија ковида 19 се по својим размерама и последицама може и мора сагледавати са медицинско-биолошког, безбедносног, економскополитичког и социопсихолошког угла. Криза изазвана вирусом са којом се свет суочио у јеку динамичке промене своје безбедносне архитектуре представљаће вредну лекцију и путоказ у сагледавању нових безбедносних феномена данашњице, али и у јачању ресурса и капацитета држава за одговор на ванредне ситуације и пандемије и могућности међународне сарадње у овом домену са доминантним ослонцем на властите ресурсе.

Кључне речи: ковид 19, пандемија, здравствени и безбедносни аспекти, ресурси.

\section{УВОД: ФАКТИ О ИЗАЗИВАЧУ ГЛОБАЛНЕ ПОШАСТИ}

Велике епидемије и пандемије утицале су на токове историје и осим здравствених, имале су одувек геополитичке, економске, еколошке и социопсихолошке последице. Од Јустинијанове куге, до шпанског, птичјег и свињског грипа, ХИВ-а, CAPC-а, MEPC-а и еболе, па до ове последње изазване SARS-2-CoV (ковид 19), коју је Светска здравствена организација (С30) прогласила 11. 3. 2020. године, мада је по званичним и незваничним показатељима вирус и много раније био у популацији и циркулацији и која је до сада однела скоро милион људских живота, сваку епидемију и пандемију пратиле су разне контроверзе, почевши од појмовног одређења пандемије, које је промењено пред пандемију свињског грипа 2009. године до геополитичког тренутка у коме се иста дешавала.

Из пандемије коронавируса, која тренутно потреса свет, стручна и научна јавност научиће свакако пуно, јер је свака пандемија јединствен догађај, баш као и вирус који ју је изазвао, који је по својој структури сличан, али ипак различит од осталих коронавируса које познајемо од 1960-тих година. Њихово зоонотско порекло, резервоари и извори, као и молекулска структура били су предмет опсежних научних истраживања и на нашем простору још 80-тих година прошлог века, када је коронавирус детектован у ћелијама бубрега пацијенткиње са балканском

\footnotetext{
${ }^{1}$ Војномедицинска академија, Универзитет одбране у Београду; e-mail: elizabeta.ristanovic@vma.mod.gov.rs
} 
ендемском нефропатијом. Досадашња сазнања иду у прилог чињеници да је ковид 19 вирус ипак другачији од осталих припадника исте фамилије (посебно САРС-а и MEPC-а вируса) по брзини ширења, рецепторима за које се везује (ACE-2), што директно утиче на имунопатогенезу и клиничке манифестације болести.

\section{ОТВОРЕНА ПИТАЊА И НЕПОЗНАНИЦЕ}

Многа сазнања, објављени радови и ауторитети у области вирусологије и имунологије буде сумњу у прилог вештачког порекла вируса и присуства секвенци ХИВ вируса у њему. Још увек су непознаница и модел и динамика, као и трајање имунског одговора на овај вирус, хуморалног (ИгМ, ИгГ, ИгА антитела), а посебно ћелијског имунитета посредованог Т-лимфоцитима, о коме се може судити само на основу искуства са сродним вирусима, као што је САРС, где су меморијски Т-лимфоцити налажени код пацијената и годинама након прележане инфекције, али и његова променљивост, што је у старту отворило питање ефикасности и ефективности вакцина за којима је почела трка међу најпроминентнијим актерима на светској политичкој сцени и оправданости медијски подгрејане претње од појаве „наредних таласа“ болести. Беспоштедна међународна утакмица тренутно се води и у домену производње вакцина. Тренутно је званично регистрована само руска вакцина Спутњик В, која је заснована на платформи коришћења хуманог аденовируса као носача имуногених сегмената ковида 19. Произвођач је Институт Гамалеја из Москве, који је једини у свету има лиценцу за производњу вакцине против еболе и велико искуство у овој области. Бројни други институти и на истоку и на западу баве се тренутно овим проблемима. Информисање јавности о овом проблему, масовна хистерија, бројне теорије завере које се (не)случајно пласирају преко друштвених мрежа, указују на потребу развоја стратегије антикризног информационог одговора, који је изузетно важан, као и кредибилитет комуникатора, указујући на то да питање кризне комуникације није и не сме бити само проблематика којом ће се бавити професионални портпароли, већ пре свега људи од струке који се у својим професионалним доменима суочавају са кризом.

Отворена су и бројна питања и контроверзе везане за саму дијагностику и лечење, поузданост, осетљивост и специфичност коришћених тестова, дијагностичке и терапијске протоколе, коришћење респиратора, могућности изолације вируса, мера превенције које се ипак на крају, као и на почетку, своде на заштитне маске, прање руку и избегавање контаката, али и приступе у борби са епидемијом, који су примењивани у различитим државама, од потпуног карантина (lock-down) до либералног модела, преко електронске контроле присутне у земљама југоисточне Азије, да би се на крају разумела неопходност избалансираног приступа између епидемије, безбедности и економије, тј. саме егзистенције система и држава.

Доносиоци одлука извући ће поуке колико је битно имати снажан и добро организован здравствени систем, са акцентом на јавно здравље и превентивну медицину, који су често у скоријој прошлости и код нас губили битку пред налетом високо софистицираних медицинских технологија и приватног 
здравства. Сектор безбедности ће свакако анализирати ствари из свог угла, не заборављајући и симулациони експеримент пандемије изазване респираторним вирусом изведен на Џон Хопкинс Универзитету у САД крајем 2019. године, која би однела 65 милиона људских живота. Анализом научних радова објављених у еминентним научним журналима претходних година, као и закључцима и упозорењима са међународних безбедносних форума одржаних у претходном периоду, која су се могла чути јавно, наслутити или прочитати између редова, такође ће се сви заједно бавити и разумеће зашто будућност припада микроорганизмима, које не можемо победити, јер су најстарији и највиталнији облик живота на планети. Наравно, док се здравствени сегмент у ходу реорганизује, схвата се и колики је данас значај молекуларне биологије, не само у карактеризацији и генетској анализи већ и у дијагностици и лечењу, као и у могућностима које развој ове науке отвара за све могуће злоупотребе, а постају јаснији и значај и улога ветеринарске медицине, јер је више од 65\% микроба зоонотског порекла, као и АБХО службе у супротстављању оваквим претњама и потреби истинског мултисекторског, интердисциплинарног приступа у решавању проблема. Уосталом, све у природи је нераскидиво повезано, како каже еколошка наука законитости.

\section{ГЕОПОЛИТИЧКЕ ИМПЛИКАЦИЈЕ И МЕЪУНАРОДНА СОЛИДАРНОСТ}

О томе најбоље сведочи и чињеница да је паралелно са зауздавањем епидемије у здравственом смислу кренуло и геополитичко надмудривање и међусобно оптуживање најмоћнијих актера на светској политичкој сцени, која свакако након ове пандемије неће бити иста. У позадини битке са вирусом одвија се жесток окршај глобалиста и суверениста за превласт унутар држава или између њих. Заражавање великог броја носилаца власти у најмоћнијим земљама света или њихових најближих сарадника такође је сегмент коме треба обратити посебну пажњу из обавештајно-безбедносног угла, као и чињеница да је, случајно или не, управо ова 2020. година у великом броју земаља света, укључујући најмоћније, попут САД, изборна година, а да ће од исхода избора зависити безбедносна архитектура будућег света. Промена Устава Русије, покушаји бројних обојених револуција у свету, блискоисточно питање, такође су се нашли у позадини велике пандемијске игре, као и развој новог дипломатског правца - медицинске дипломатије, у чему је највећи продор остварила НР Кина.

Ако узмемо у обзир и моћ медија и друштвених мрежа, снагу дезинформација као моћног оружја хибридног војевања и утицај на формирање атмосфере страха и панике, као и социопсихолошког инжењеринга и неминовне драстичне економске последице на светском нивоу, јасно је да инфективни агенси могу бити учинковитији од класичног рата и да будућност ратовања свакако припада биолошким и другим хибридним формама рата, као и да се за исте треба благовремено припремати. У том сегменту треба посебно апострофирати значај и улогу система одбране у целини, што се види и кроз ефикасан ангажман војске у многим државама света, посебно модерног и добро организованог војног здравства и његове превентивномедицинске службе. 


\section{ИСКУСТВА И ЛЕКЦИЈЕ}

Свет је данас уздрман и дрхти пред коронавирусом, чија се стопа смртности код нас тренутно процењује на око $1,65 \%$ одсто. Према званичним подацима, у Републици Србији је до 03. 11. 2020. године ПЦР тестом присуство генома вируса детектовано код 51.083 особа, а забележено је 844 смртних случајева. Наша земља се ослања на сопствене ресурсе, добру организацију, знање и посвећеност, као и на искрене и проверене пријатеље, пре свега Русију и НР Кину, тако да се успешно ухватила у коштац са овом епидемијом, која је на површину избацила све мањкавости оних држава и здравствених система који су словили за најорганизованије и најбогатије и годинама нам у том својству делили лекције о томе у ком правцу треба да иде „реформа“ нашег здравства. На ефикасан одговор нашег здравства сигурно је утицала одлучна и апсолутна подршка државе, али је пресудан значај имало и знање и одговоран приступ наших лекара, пре свега епидемиолога и инфектолога, али и искуства која смо стицали суочавајући се са разним епидемијама заразних болести кроз историју, буре и ратове, попут тифуса, вариоле, туларемије, хантавируса, али и кроз појаву неких опасних патогена, који су представљали истинску пробу за наш здравствени систем, за нашу струку и науку, попут марбург вируса, сродником еболе, са којим смо се сусрели 1967. године. Томе треба додати колективни дух, осећај припадности и јединства, наше препознатљиве етнопсихолошке карактеристике, које посебно долазе до изражаја у тренуцима кризе.

Ипак, када се све заврши, неопходно је извршити темељну и свестрану анализу свих сегмената одговора друштва на пандемијски изазов, уочити слабости и схватити кризу као развојну шансу за унапређење капацитета на стратегијском, тактичком и оперативном нивоу, од образовања, снажења свих ресурса, до кризног менаџмента и кризне комуникације како бисмо у будућности још ефикасније могли да се ухватимо у коштац са оваквим изазовима. Велики проблем представља образовни систем и прелазак на режим онлајн образовања, који дугорочно може да остави несагледиве последице по ментални, когнитивни и духовни развој деце и омладине. Честа примена термина социјална дистанца, уместо физичке, као и дуготрајни карантин могу такође имати социопсихолошке последице, а посебно по здравље кардио-васкуларних болесника. Велика опасност и велика жртва могао би да постане и сам здравствени систем, јер се због оптерећености и фокусирања пажње на ковид 19 позитивне пацијенте занемарују други проблеми и патологије.

У сваком случају, након искуства са епидемијом ковида 19 потпуно је јасно да међународна солидарност не постоји, што се најбоље видело на примеру Италије, и да морамо даље, организовано и плански, да увећавамо снаге за одговор на овакве кризне ситуације, ослањајући се на властите ресурсе, али не занемарујући искуства других и научене лекције, анализирајући и сопствене кораке, реализоване мере, али и слабе тачке. Потребно је радити на ревитализацији капацитета за дијагностику, производњу лекова и вакцина, бавити се научноистраживачким радом и јачањем здравствене и војноздравствене службе, као и медицинског обавештајног рада и контраобавештајне заштите. Подсетимо 
да смо некада имали снажан Институт Торлак, сопствену производњу вакцина и различитих дијагностикума, као и терапијских средстава (нпр. интерферон типа, који има антивирусно дејство), као и респектабилне РХБ системе у оквиру безбедносног сектора, по чему је некадашња Југославија била једна од водећих земаља у свету.

\section{ЗАКЉУЧАК}

Микроорганизми имају своје законитости и желе да очувају свој витални потенцијал, а климатске промене, активности човека, миграције или биолошки ратови могу овој претњи да дају несумњив специфични допринос. Свакако да ће ова пандемија можда бацити ново светло и на биотероризам и његове перспективе у контексту аспирација које се могу појавити код потенцијалних извршилаца, па самим тим посебну пажњу треба посветити сегменту биолошке безбедности и биолошке сигурности. Војничким речником, вежбе, симулације и маневри дешавају се у предвечерје ратних дејстава. Сходно томе, можда је ова пандемија, колико год била озбиљна по значају и последицама, само увертира за озбиљније претње са којима се у будућности можемо суочити.

\section{ЛИТЕРАТУРА}

- Ристановић Елизабета, „Здравствени аспекти COVID-19 у огледалу реалног времена.“ у: Зоран, Кековић (ур.), Збирка ауторизованих предавања са семинара одржаних за време пандемије. Центар за анализу ризика и управљање кризама и Институт за стандардизацију Србије, Београд, 2020, стр. 29-42.

- Кокошков, Ненад и Ристановић, Елизабета. „Медицинско-обавештајно деловање према истакнутим личностима“, Национална безбедност: Научни часопис за безбедносне науке, бр. 9, 2019.

- Cao, X., “COVID-19: immunopathology and its implications for therapy." Nature reviews immunology, Vol. 20, No. 5, 2020, pp. 269-270.

- Bai Y., Yao L., Wei T., Tian F., Jin D. Y., Chen L., \& Wang, M. “Presumed asymptomatic carrier transmission of COVID-19.” Jama, Vol. 323, No. 14, 2020, pp. 1406-1407.

- „Корона вирус: Covid-19“, Министарство здравља Републике Србије и Институт за јавно здравље „Др Милан Јовановић Батут“, https://covid19.rs/, 30/08/2020.

- Ristanovic Elizabeta, Kokoškov Nenad, Crozier Ian, Kuhn Jens, Gligic Ana. “A forgotten episode of Marburg virus disease: Belgrade, Yugoslavia, 1967." Microbiology and Molecular Biology Review, Vol. 84, No. 2, 2020, pp. 1-22.

\section{HEALTH AND SECUIRTY ASPECTS OF COVID-19}

Abstract: By its dimensions and consequences, the COVID-19 pandemic can and must be observed from medical, biological, security, economic, political and socio- 
psychological aspect. The crisis caused by the virus, which the world faced during the height of the dynamic change in its security architecture will represent a valuable lesion and a roadmap towards observing new security phenomena of today, but also through the prism of strengthening resources and capacities of states for responses and pandemics, as well as the possibilities of international cooperation within this domain with predominant reliance on domestic resources.

Key words: COVID-19, pandemic, health and security aspects, resources. 